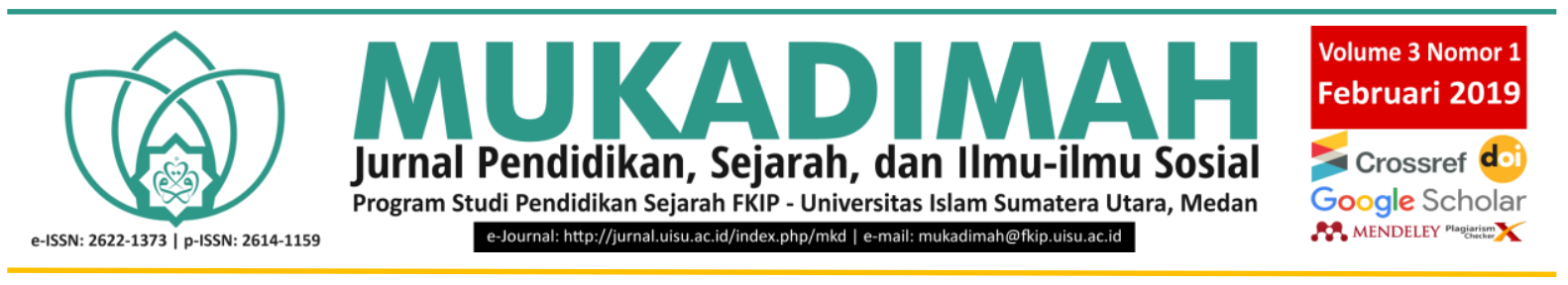

\title{
STRATEGI KOMUNIKASI DALAM RESOLUSI KONFLIK UMAT BERAGAMA DI KOTA TANJUNG BALAI
}

\author{
Sahdin Hasibuan* \\ Fakultas Dakwah dan Komunikasi - Universitas Islam Negeri Sumatera Utara, Medan
}

\begin{tabular}{|c|c|}
\hline Article History & Abstrak \\
\hline Received : January, 2019 & \multirow{5}{*}{$\begin{array}{l}\text { Artikel ini bertujuan membahas strategi komunikasi dalam resolusi } \\
\text { konflik umat beragama di Kota Tanjung Balai, berbagai macam kegiatan } \\
\text { komunikasi dalam meredam konflik keagamaan telah dilakukan oleh } \\
\text { pihak-pihak yang terkait. Dengan melihat berbagai macam keadaan yang } \\
\text { ada mengenai kehidupan sosial masyarakat pada Kota Tanjung Balai, } \\
\text { komunikasi dalam dialog keberagaman dilakukan oleh para pihak } \\
\text { pemuka agama dari lintas keagamaan. Penelitian ini mengandalkan } \\
\text { metode studi lapangan (field research) dan studi pustaka (library } \\
\text { research). Penelitian ini dilakukan di Kota Tanjung Balai dengan } \\
\text { mengunjungi beberapa lembaga keagamaan yang terkait serta instansi } \\
\text { pemerintahan, dan masyarakat sekitar yang berada pada saat kejadian. } \\
\text { Adapun yang dapat diperoleh dari data hasil penelitian antara lain: 1) } \\
\text { Upaya peningkatan kesejahteraan sosial melalui bidang ekonomi; 2) } \\
\text { Dialog dan komunikasi oleh Forum Kerukunan Umat Beragama (FKUB); } \\
\text { 3) Pemerintah, Departemen Agama, dan Pihak MUI yang berupaya untuk } \\
\text { berkomunikasi dengan pihak yang terlibat melalui dialog lintas } \\
\text { keagamaan. }\end{array}$} \\
\hline Accepted : January, 2019 & \\
\hline Published : February, 2019 & \\
\hline Kata Kunci & \\
\hline $\begin{array}{l}\text { Strategi komunikasi, resolusi } \\
\text { konflik, Tanjung Balai. }\end{array}$ & \\
\hline
\end{tabular}

\section{PENDAHULUAN}

Konflik belakangan ini sering terjadi, baik dalam skala lokal, regional, nasional dan dalam lingkup internasional, baik konflik antar umat beragama, antar etnis atau konflik lainnya. Istilah konflik (conflict) oleh para pakar dalam berbagai literatur, mengandung banyak pengertian. Dalam Kamus Lengkap Pemikiran Sosial Modern, misalnya, Lewis Coser didefinisikan sebagai perseteruan atas nilai atau klaim status, kekuasaan, dan sumber daya yang langka, di mana tujuan dari pihak yang berkonflik bukan hanya mendapat apa-apa yang diinginkannya tetapi juga menetralkan, melukai, atau menghilangkan rivalnya. Konflik bisa terjadi antar-individu atau antar-kelompok. Konflik antar-kelompok dan konflik dalam kelompok adalah ciri abadi dari kehidupan sosial; konflik adalah komponen esensial dari interaksi sosial di setiap masyarakat (Outhwaite, 2008, p. 142).

Menurut Sigmund Freud, konflik adalah pertentangan antara dua kekuatan atau lebih, mengandung agresivitas dan diekspresikan. Selanjutnya, Schermerhorn, Hunt dan Osborn menyatakan bahwa konflik terjadi pada saat muncul ketidaksepakatan dalam situasi sosial yang ditandai oleh friksi emosi antara individu atau kelompok (Koeswinarno \& Abdurrahman, 2006, p. 5). Walaupun demikian, konflik bukan berarti selalu merupakan "faktor negatif" yang melemahkan kehidupan kolektif. Konflik sering berperan dalam pemeliharaan dan perkembangan kelompok dan memperkuat relasi antar-orang (Outhwaite, 2008, p. 142).

How to Cite (APA $6^{\text {th }}$ Edition style):

Hasibuan, Sahdin. (2019). Strategi Komunikasi dalam Resolusi Konflik Umat Beragama di Kota Tanjung Balai. MUKADIMAH, 3(1), 42-51. 
Konflik atau pertentangan bisa timbul di dalam diri seseorang (masalah intern) maupun dengan orang lain (masalah ekstern) yang ada di sekitarnya. Konflik dapat berupa perselisihan (disagreement), adanya ketegangan (the presence of tension), atau munculnya kesulitan-kesulitan lain di antara dua pihak atau lebih. Konflik sering menimbulkan sikap oposisi antar kedua belah pihak, sampai kepada mana pihak-pihak yang terlibat memandang satu sama lain sebagai pengahalang dan pengganggu tercapainya kebutuhan dan tujuan masing-masing.

Setiap pertentangan, permusuhan, perang, atau konflik apapun bentuk dan lingkupnya, komunikasi merupakan solusi terbaik dalam mengatasinya. Konsep komunikasi penting untuk bidang yang beragam. Masing-masing menggunakan istilah ini dengan caranya yang khas. Memang komunikasi telah digunakan dalam banyak hal dan dalam banyak konteks.

Penelitian ini akan mengekplorasi komunikasi yang dilakukan terkait konflik umat beragama antara komunitas muslim dengan komunitas Budhis etnis Tionghoa yang berlangsung selama enam tahun lebih (2010-2016) di Kota Tanjung Balai. Konflik secara spesifik terkait dengan pendirian rupang atau patung Amithaba di atas Vihara Tri Ratna yang mendapat protes dari komunitas muslim atau Gerakan Islam Bersatu (GIB) dan protes seorang etnis Tionghoa bernama Meliana terkait dengan suara keras sound Masjid Al-Makshum di kota tersebut.

Puncak atau eskalasi konflik terjadi pada tanggal 29 Juli 2016 yaitu aksi kerusuhan dan pembakaran 15 bangunan dan penjarahan rumah ibadah etnis Tionghoa di Tanjung Balai pada akhir Juli 2016. Terlepas dari dari apakah konfli kini bernuansa agama atau konflik ekonomi tidak lah begitu penting, karena sumber konflik bisa saja ekonomi, tetapi tanpa mendapat justfikasi agama dan power konflik etnisitas, konflik ini tidak akan meluas dan mendapat dukungan banyak pihak yang berkonflik. Karena itu, melekatkan agama sebagai salah satu varian potensial pemicu kekerasan adalah hal yang tidak mudah. Ini karena agama dianggap sebagai ajaran yang selalu diasosiasikan dengan ajaran yang sarat dengan nilai kedamaian dan keselamatan (Hasibuan, 2017, p. 224).

\section{HASIL DAN PEMBAHASAN}

Tanjung Balai pada masa lalu merupakan kota pelabuhan dan pusat pemerintahan Kerajaan Asahan. Pada era kolonial Belanda, Tanjung Balai pernah menjadi kota Afdeeling (setingkat Kabupaten) tempat kedudukan seorang Assisten Resident. Gementee (Kotapraja) Tanjung Balai didirikan berdasarkan Besluit Gubernur Jenderal tanggal 27 Juni 1917, No. 284 dengan luas wilayah 106 Ha. Pada tahun 1956, berdasarkan Undang-Undang Darurat No. 9 tahun 1956 (Lembaran Negara 1956 No. 6o) nama Gemeente Tanjung Balai diubah menjadi Kota Tanjung Balai dan jabatan Walikota terpisah dari Bupati Asahan (berdasarkan surat Menteri Dalam Negeri tanggal 18 September 1956 No. U.P. 15/2/3). Setahun berselang, melalui UU No. 1 Tahun 1957 nama Kota Kecil Tanjung Balai diubah menjadi Kotapraja Tanjung Balai.

Kondisi sosial-budaya di Kota Tanjung Balai meliputi masyarakat yang punya perpaduan antar etnis yang sudah membaur menjadi sebuah kebudayaan orang pesisir. Begitu unik dan menarik campuran etnis Batak, Padang, Karo, Mandailing, Tionghoa 
dan lainnya sehingga tercipta kultur masyarakat yang rukun. Secara ekonomis kondisi Kota Tanjung Balai sangat strategis dan menguntungkan. Hal ini terlebih lagi dengan dukungan sarana dan prasarana, infrastruktur dan aksesibilitas yang cukup memadai, baik berupa transportasi darat, laut, jaringan air bersih, listrik, dan telekomunikasi yang dapat menjangkau seluruh wilayah.

Perencanaan pembangunan ekonomi dimulai dengan penetapan tujuan pembangunan ekonomi yang diselaraskan dengan visi dan misi kepala daerah yakni melaksanakan pembangunan ekonomi yang bertumpu kepada sektor industri dan perdagangan dengan memaksimalkan fungsi pelabuhan. Upaya-upaya pembangunan ekonomi dilakukan melalui langkah-langkah strategis di bidang ekonomi dengan memperhatikan potensi dan kondisi wilayah yang ada, selanjutnya dituangkan ke dalam program dan kegiatan yang hakekatnya merupakan serangkaian usaha dan kebijakan yang bertujuan untuk membuka peluang kesempatan kerja dan meningkatkan pendapatan per kapita yang akhirnya dapat meningkatkan kesejahteraan masyarakat.

Berdasarkan letak geografis yang sangat strategis, maka potensi Kota Tanjungbalai yang dapat dikembangkan antara lain:

1) Sebagai Pusat Pelayanan Sekunder A yakni Pusat Pembangunan Kawasan Sektor Unggulan meliputi: Perkebunan, Pertanian dan Industri terhadap wilayah hinterland sesuai Peraturan Daerah Provinsi Sumatera Utara Nomor 7 Tahun 2003 tentang Rencana Tata Ruang Wilayah Provinsi Sumatera Utara.

2) Sebagai jalur transit perdagangan internasional dari negara tetangga seperti Malaysia dan Singapura dan Pelabuhan alternatif bagi daerah hinterland, seperti: Kabupaten Asahan, Kabupaten Labuhan Batu, Kabupaten Simalungun, Kabupaten Tapanuli Selatan, Provinsi Riau Kepulauan, Pesisir Provinsi Riau dan kota-kota besar lainnya di Sumatera Utara.

3) Mempunyai lahan yang cukup luas dan produktif untuk pengembangan sebagai kota industri, perdagangan, pelayanan jasa telekomunikasi yang didukung oleh Pelabuhan Teluk Nibung sebagai andalan keluar masuk barang (ekspor-impor) dan penumpang.

4) Dapat dilalui dengan sarana transportasi baik darat maupun sungai.

5) Fasilitas andalan yang tersedia seperti: jaringan air minum, listrik, transportasi darat dan kereta api, sarana pendidikan, sarana kesehatan, serta sarana lainnya.

6) Sumber daya alam yang tersedia seperti : kandungan mineral, galian Sungai Silau dan Sungai Asahan.

7) Mempunyai sumber daya alam yang dapat dikembangkan di sektor perikanan khsususnya perikanan tangkap dan budidaya.

8) Sumber daya manusia yang dapat dikembangkan.

\section{Konflik Keagamaan di Tanjung Balai dan Komunikasi Pihak yang Terlibat Pasca Konflik}

Komunikasi antar umat beragama di Kota Tanjung Balai pada semua kalangan bisa berjalan harmonis jika aturan yang tertera yang dikeluarkan oleh pemerintah mengenai umat beragama bisa diterapkan sebagaimana mestinya. Pemerintah menjalankan tugas dan kewajibannya sesuai aturan, demikian pula halnya dengan masyarakat. Sebenarnya masyarakat Kota Tanjung Balai ini sangat toleran satu sama 
lain dan juga sangat ramah terhadap sesama, akan tetapi kadang ada orang-orang yang tidak bertanggungjawab yang merusak semua itu dengan memprovokasi masyarakat untuk melakukan konflik ataupun insiden yang pada akhirnya meresahkan masyarakat. Kondisi semacam itu hanya bisa diatasi dengan kerjasama yang baik antara pemerintah dan masyarakat dalam mewujudkan perdamaian di Kota Tanjung Balai.

Untuk memprediksi pencegahan dan resolusi konflik perlu mengidentifikasi sumber kekuasaan dengan kajian teori yang memadai, di antaranya dengan kajian struktural, kelembagaan dan unsur budaya yang berkaitan dengan konteks domestik dan juga memfokuskan pada suatu "barang" untuk bahan evaluasi sebagai faktor asal potensi ketidakstabilan lingkungan. Perspektif struktural konflik, berkaitan dengan berbagai kelompok sosial, kelompok kepentingan dan sumber kepentingan. Serta terjadinya perubahan akses terhadap distribusi sumber ekonomi dan politik. Demikian pula aspek kecocokan makna infrastruktur bagi etnik dan mobilisasi sosial bagian penting dari kajian konflik. Peningkatan konflik terjadi pula apabila ada ketidaksamaan materi dan adanya diskriminasi minoritas lokal yang menyebabkan timbulnya lingkungan stres (Sulaeman, 2015, p. 45).

Selanjutnya Wolfe menjelaskan perihal resolusi konflik yang harus mengorganisir akar rumput ikut aktif ke dalam proses membangun perdamaian, yaitu dengan membangun akses akar rumput terhadap sumber (kemampuan, material, pribadi, informasi), kepemimpinan, tetapi yang lebih baik lagi peningkatan kepercayaan dan mencari pemahaman tingkat lokal (Sulaeman, 2015, p. 45).

Untuk resolusi konflik menurut Wolfe ada 6 langkah rekomendasi yaitu (Sulaeman, 2015, p. 45):

1) Dalam membuat keputusan mempertinggi kesadaran kepada metode asli pribumi.

2) Menginventarisir dan meringkaskan sistem pengelolaan lokal (indegenous) lintas etnis dan siap diaplikasikan.

3) Membuat unsur budaya yang tidak nampak lebih nampak dan menyatukan pengetahuan etnografi dengan ilmu sosial lainnya.

4) Menempatkan tujuan isu-isu yang tak terpecahkan sebagai tingkat dan unit analisis, mulai dari isu individu, keluarga, kelompok dan institusi atau komunitas yang lebih luas.

5) Menggali alat dan sistem: pengetahuan, simbol, nilai dan pola aktivitas dan aplikasi asli tentang resolusi konflik.

6) Mengumpulkan berbagai hasil analisis tentang persyaratan masyarakat damai.

Selanjutnya Wolfe menjelaskan apa dan bagaimana proses negosiasi, bentuk dan proses negosiasi sumber yang digunakan adalah kekuasaan, pola komunikasi kesukaan formasi dan modifikasi, strategi dan taktik, serta mengenal variasi nilai, tujuan dan makna. Kemudian fase pencegahan konflik menurut Leatherman adalah: pencegahan konflik struktural, kelembagaan, kultural dan ekonomi; pencegahan eskalasi konflik vertikal dan horisontal, mengintegrasikan dan merekontruksi supaya tidak timbul lagi (Sulaeman, 2015, p. 45). 
Indonesia dikenal sebagai suatu sosok masyarakat yang pluralistik dalam hal agama, tradisi, kesenian, kebudayaan, cara hidup dan pandangan nilai yang dianut oleh kelompok-kelompok etnis dalam masyarakat Indonesia. Pada suatu sisi pluralistik bisa menjadi positif dan konstruktif tetapi di sisi lain juga bisa menjadi sebuah kekuatan yang negatif dan destruktif yang dapat berakibat pada terjadinya disintegrasi bangsa. Kenyataannya sejarah masyarakat adalah multi-complex yang mengandung religious pluralism. Hal ini adalah realitas, karena itu mau tidak mau kita harus menyesuaikan diri, dengan mengakui adanya religious pluralism dalam masyarakat Indonesia (Imarah, 1999, p. 11).

Di dalam konflik antar agama itu sendiri muncul tindakan yang justru bertentangan dengan ajaran agama, dikarenakan emosi yang tidak dapat terkendali sehingga dengan mudahnya mereka bertindak yang sebenarnya telah keluar dari nilainilai ajaran agama. Jika dikaitkan antara ajaran agama dan tingkah laku umat yang membakar tempat ibadah dan membunuh sesama umat sungguh sangat kontroversial. Padahal semua agama mengajarkan betapa pentingnya kerukunan dan kedamaian. Kalau pun terjadi konflik antarumat beragama, maka bukanlah ajaran agamanya yang salah namun umat atau pemeluk agama itu sendirilah yang sempit dalam memahami ajaran agama.

Terjadinya konflik tidak terlepas dari adanya dalang atau provokatornya tidak pernah diusut tuntas. Sehingga wajar jika masyarakat menuntut pemerintah bertindak tegas menangkap provokatornya. Dari berbagai kerusuhan, teror, fitnah dan pembunuhan memang sedang melanda bangsa kita sehingga untuk menghadapi berbagai bencana tersebut, maka semua pihak hendaknya senantiasa waspada. Sebab, berbagai cara akan dilakukan oleh provokator untuk mengadu domba antar umat beragama, antar suku dan antar etnis sehingga persatuan dan kesatuan menjadi rapuh (Daulay, 2001, p. 138). Oleh karena itu, setiap umat beragama senantiasa berpegang teguh pada ajaran agamanya, agar mereka tidak akan terjebak pada isu-isu yang disampaikan pada mereka.

Konflik sebagai akibat dari menajamnya perbedaan dan kerasnya benturan kepentingan yang saling berhadapan, disebabkan oleh beberapa latar belakang yang ada. Pertama, adanya latar belakang sosial politik, ekonomi dan sosial budaya yang berbeda dan memiliki pengaruh yang sangat kuat. Kedua, adanya pemikiran yang menimbulkan ketidaksepahaman antara yang satu dengan yang lain. Ketiga, adanya sikap tidak simpatik terhadap suatu pihak, sistem dan mekanisme yang ada dalam organisasi. Keempat, adanya rasa tidak puas terhadap lingkungan organisasi, sikap frustasi, rasa tidak senang, dan lain-lain, sementara tidak dapat berbuat apa-apa dan apabila harus meninggalkan kelompok, berarti harus menanggung resiko yang tidak kecil. Kelima, adanya dorongan rasa harga diri yang berlebih-lebihan dan berakibat pada keinginan untuk berusaha sekuat tenaga untuk melakukan rekayasa dan manipulasi (Hidayat, 2009, p. 76).

Tindakan kekerasan yang terjadi akibat dari kesalahpahaman informasi yang di dalamnya termuat sentimen agama dan etnis, kemudian berujung pada kekerasan sosial seperti; pembakaran rumah ibadah vihara, klenteng dan bangunan lainnya, memberi pelajaran kepada kita semua, bahwa pemicu konflik dapat berbentuk apa saja, di mana 
saja, dan kapan saja (Chandra, 1992, p. 16). Kerusuhan di Kota Tanjung Balai telah memberi bukti nyata bahwa kekerasan sosial bernuansa agama dan etnis sekaligus dengan motif-motif yang beragam seperti identitas keagamaan terkadang masih menjadi persoalan yang sulit untuk dihindari. Ia akan dengan mudah disulut oleh sentimen-sentimen identitas yang sesungguhnya bisa sangat sederhana (Suparto, 2014, p. 4).

Tindakan pengrusakan dan pembakaran di Tanjung Balai yang kemudian dibungkus atas nama keyakinan keagamaan seakan memberikan pesan bahwa peta harmoni dari panorama keberagaman di Indonesia menghadapi masalah serius, rapuh dengan sentimen etnis menguat. Sepertinya di dalam kehidupan masyarakat ada tandatanda yang menunjukkan sifat-sifat kebencian yang berujung pada kekerasan sosial. seperti api dalam sekam, artinya bahwa konflik identitas sosial, seperti agama, etnis, ras, selalu menuju titik kekerasan sosial, pada praktiknya apa yang terjadi di satu tempat tidak menutup kemungkinan akan terjadi di tempat lain, hanya dengan pemantik sederhana. Terlebih dalam masyarakat selalu ada unsur-unsur pembeda, majemuk atau heterogen sehingga persinggungan di dalam interaksi sosial yang bisa menyinggung perasaan salah satu pihak akan berujung pada kekerasan sosial.

Kesenjangan ekonomi, kemiskinan, hilangnya nilai-nilai moral, agama menjadi bagian yang tak terpisahkan dari tindak kekerasan, bahkan kemiskinan merupakan komponen yang paling seksi dan provokatif sebagai pemicu timbulnya kerawanan sosial. Meskipun pemicu konflik seringkali berawal dari keyakinan keagamaan, etnik, ras seperti halnya penjelasan Usman Pelly, bahwa kerusuhan etnik berakar dari kesenjangan sosial ekonomi dan merupakan protes budaya yang memberikan petunjuk kuat bahwa tatanan sosial dalam kehidupan majemuk telah dilanggar dan dihancurkan (Pelly, 1999, p. 34).

Pandangan menarik disampaikan oleh Gubernur Sumatera Utara Tengku Erry Nuradi ketika melakukan kunjungan kerja ke kota Tanjung Balai, khususnya terkait dengan pasca pembakaran rumah ibadah. Secara bersamaan gubernur juga menyinggung persoalan ketimpangan ekonomi, praktik eksklusivitas salah satu etnis yang kurang berbaur dengan etnis lain. "Sebagai panutan, tokoh masyarakat harus mampu mendinginkan dan menenangkan masyarakat supaya tidak timbul perpecahan sehingga menimbulkan kerugian dan krisis kepercayaan. Jika komunikasi terjalin dengan baik, maka peristiwa yang mencoreng kerukunan umat beragama di Kota Tanjung Balai yang telah lama terjalin dengan baik selama ini tidak perlu terjadi.” (Koran Sindo, 2016).

Tapi, di balik itu ada persoalan besar harus diselesaikan, yaitu persolan ekonomi dan eksklusivitas yang diberikan kepada masyarakat kelas atas sehingga menimbulkan kecemburuan sosial. Sumatera Utara merupakan provinsi kaya akan suku, adat istiadat, dan agama. Terdapat tiga etnis utama, yakni etnis lokal, etnis nusantara, dan etnis mancanegara. Etnis lokal yakni Batak Simalungun, Batak Toba, Batak Pakpak, Batak Karo, Batak Angkola, Batak Mandailing, suku Melayu, dan Nias. Sedangkan etnis nusantara di antaranya etnis Jawa, Minang, Aceh, Sunda, Bugis, dan Banjar. Adapun etnis mancanegara di antaranya Arab, Tionghoa, dan India."(Koran Sindo, 2016). 
Pernyataan gubernur bukan tanpa alasan bahwa terkait relasi bangunan sosial antara masyarakat di Tanjung Balai memang menghadapi masalah serius, pasca konflik rumah ibadah yang terjadi memberikan gambaran bahwa ada pola adaptasi sosial yang tidak tepat dan ketimpangan ekonomi yang kuat, ketimpangan ini justru terjadi dalam dua kutub, yaitu antara majikan dan pekerja buruh, yaitu secara umum mereka yang bekerja sebagai buruh nelayan yang dimiliki oleh majikan etnis Tionghoa.

Konflik rumah ibadah bernuansa etnis di Tanjung Balai dapat diselesaikan oleh umat beragama yang didukung oleh pimpinan agama. Upaya menangani konflik tersebut dilakukan dengan cara dialog lintas pemangku kepentingan. Secara demogafis Islam menjadi agama mayoritas di Tanjung Balai. Masyarakat Melayu pesisir memiliki fanatisme religius yang kuat. Secara struktural kokohnya pengaruh tokoh agama di masyarakat tidak dapat dilepaskan dari perannya sebagai cultural broker yaitu, kemampuan untuk menghubungkan tatanan keagamaan dengan faktor lokal. Tokoh agama sering disebut sebagai agent of change dalam masyarakat. Berpusat dari peran tokoh agama, kehidupan sosial dan politik dapat ditentukan arahnya.

\section{Strategi Komunikasi dalam Resolusi Konflik}

Resolusi konflik adalah suatu cara mengelola konflik yang bertujuan membantu orangorang yang sedang berkonflik untuk mengatasi emosinya, sehingga mereka lebih siap untuk menyelesaikan persoalan-persoalan di dalam konflik dengan cara yang digunakan melalui tindakan yang tenang dan cenderung menggunakan pikiran yang dingin. Pengelolaan konflik juga mentransformasikan konflik menjadi suatu kekuatan yang mempromosikan penghidupan berkelanjutan. Hal ini dimaksudkan untuk membantu orang mengetahui cara-cara mengatur tingkah laku mereka yang membantu mereka untuk dapat menyelesaikan apa yang dianggap sebagai perbedaan-perbedaan. Dalam konflik antar umat beragama, mengelola konflik berarti memberikan seperangkat prinsip dan alat untuk memberikan ruang terhadap masyarakat agar setiap permasalahan dapat diselesaikan dengan jalan perdamaian.

Pertama, kearifan lokal sebagai penanda identitas sebuah komunitas. Identitas tersebut menunjukkan bahwa komunitas tersebut memiliki budaya perdamaian yang berarti menunjukkan komunitas tersebut merupakan komunitas yang beradab. Hal ini dikarenakan konflik merupakan simbolisasi kultur barbarian. Tentunya dengan memiliki kearifan lokal, komunitas tersebut ingin mencitrakan dirinya sebagai komunitas yang cinta damai. Kedua, kearifan lokal sendiri menyediakan adanya aspek kohesif seperti elemen perekat lintas agama, lintas warga, dan kepercayaan. Kearifan lokal dapat diartikan sebagai ruang dan arena dialogis guna melunturkan segala jenis esklusivitas politik identitas yang melekat di antara berbagai kelompok. Upaya menjembatani berbagai lintas kepentingan adalah upaya untuk membangun inklusivitas dalam meredam potensi konflik yang lebih besar. Ketiga, berbeda halnya dengan penerapan hukum positif sebagai media resolusi konflik yang selama ini sering dilakukan para penegak hukum dan terkesan "memaksa". Hal inilah yang menjadikan resolusi konflik dengan hukum positif sendiri justru sifatnya artifisal dan temporer meskipun memiliki kekuatan hukum tetap. Banyak kasus anarkisme agama yang diselesaikan melalui pendekatan hukum positif seperti halnya SKB Tiga Menteri sering mandeg dan jalan di tempat, bahkan lebih banyak dilanggar. Kearifan lokal sebagai 
bagian dari resolusi konflik alternatf justu lebih ke arah mengajak semua pihak untuk berunding dengan memanfaatkan kedekatan emosi maupun kultural. Keempat, kearifan lokal memberi warna kebersamaan bagi sebuah komunitas dan dapat berfungsi mendorong terbangunnya kebersamaan, apresiasi, sekaligus sebagai sebuah mekanisme bersama menepis berbagai kemungkinan yang dapat meredusir, bahkan merusak solidaritas komunal, yang dipercaya berasal dan tumbuh di atas kesadaran bersama, dari sebuah komunitas yang terintegrasi. Kelima, Kearifan lokal akan mengubah pola pikir dan hubungan timbal balik individu dan kelompok, dengan meletakkan di atas kebudayaan yang dimiliki. Maka bisa dikatakan bahwa kearifan lokal merupakan bentuk sintesa dari unsur sosio-kultural dan sosio-keagamaan yang tujuannya adalah merekatkan kembali hubungan antar sesama masyarakat yang tereduksi perebutan kepentingan politik maupun ekonomi (Ridwan, 2007, p. 31).

Untuk mencegah konflik yang terjadi di Tanjung Balai semakin memanas maka perlu diadakannya beberapa mekanisme yang dapat di pilih, misalnya: Membentuk forum yang berasal dari berbagai bagian masyarakat untuk diadakannya musyawarah agar kiranya menemukan titik damai, Mengirim sesepuh dari marga, suku, atau kelompok adat dengan yang dimaksud adalah golongan tua dengan maksud sebagai utusan untuk melakukan dialog perdamaian, sebagai pembuktian agar tidak akan terulang lagi nilai-nilai sentimentil pada diri masyarakat, mengundang tokoh-tokoh agama dari lintas agama untuk melakukan intervensi, dengan tujuan menyediakan ruang untuk mengumpulkan seluruh masyarakat dari lintas agama sebagai wujud persatuan, memanfaatkan ritual yang ada dengan tujuan untuk membawa orang bersama-sama memperhatikan nilai-nilai yang ada.

Pada dasarnya strategi komunikasi merupakan paduan dari perencanaan komunikasi dengan maksud untuk mencapai suatu tujuan. Untuk mencapai tujuan tersebut strategi komunikasi harus dapat menunjukkan bagaimana pelaksanaan operasional secara taktis dilakukan, dalam arti bahwa pendekatan yang dilakukan bisa berbeda-beda tergantung pada situasi dan kondisi. Anwar Arifin mengungkapkan bahwa berbicara tentang strategi komunikasi, berarti berbicara tentang bagaimana sebuah perubahan diciptakan pada khalayak dengan mudah dan cepat. Perubahan merupakan hasil proses komunikasi yang tak terelakkan. Semua pihak yang berkomunikasi, mau tidak mau pasti mengalami perubahan baik perubahan kecil maupun perubahan besar (Arifin, 1984, p. 10).

Di dalam perlindungan terhadap kerukunan umat beragama dalam kehidupan bermasyarakat sudah menjadi tanggung jawab semua pihak, terutama bagaimana meningkatkan SDM dan Lembaga Kerukunan sesuai dengan keinginan umat, bangsa dan negara. Tindakan MUI, pihak Kepala Departemen Agama dan Pemerintah Daerah Tanjung Balai, melakukan musyawarah dan mengumpulkan pihak-pihak yang terlibat dalam konflik keagamaan.

Selain pemuka agama dalam kerangka pemeliharaan kerukunan umat beragama juga menjadi tugas Kepala Daerah seperti yang tercantum dalam Peraturan Bersama Mendagri Nomor 9 Tahun 2006 dan Nomor 8 Tahun 2006 tentang pedoman tugas Kepala Daerah dalam pemeliharaan kerukunan beragama, pemberdayaan forum kerukunan umat beragama dan pendirian rumah ibadah terdapat pada BAB II Tentang 
Tugas Kepala Daerah dalam pemeliharaan kerukunan umat beragama dalam pasal 2, 3, 4, 5, 6, 7; serta BAB III Forum Kerukunan Umat Beragama di dalam pasal 8, 9, 10, 11, 12.

Jadi kerukunan umat beragama dalam kehidupan bermasyarakat sudah dilegalisir oleh pemerintah karena mempunyai tugas untuk memberikan bimbingan dan pelayanan agar setiap penduduk dalam melaksanakan ajaran agamanya dapat berlangsung dengan rukun, lancar dan tertib, dan untuk daerah dalam rangka menyelenggarakan otonomi, mempunyai kewajiban melaksanakan urusan wajib bidang perencanaan, pemanfaatan dan pengawasan tata ruang serta kewajiban melindungi masyarakat, menjaga persatuan, dan kerukunan nasional serta keutuhan negara Kesatuan Republik Indonesia terutama pada daerah Tanjung Balai.

Untuk mewujudkan komunikasi antar umat beragama, Pemerintah Kota Tanjung Balai telah membentuk Forum Kerukunan Umat Beragama (FKUB) Kota Tanjung Balai. Forum didirikan oleh masyarakat yang mewakili keberadaan agama dan disahkan oleh pemerintah. FKUB didirikan pada tingkat kota sampai ke tingkat kecamatan sebagai sebuah media untuk berkomunikasi antar umat beragama. Kehadiran FKUB merupakan upaya untuk memfasilitasi komunikasi yang mengarah pada keharmonisasian dan dinamisasi pembangunan hubungan internal umat beragama, antar umat beragama, dan antar umat beragama dengan pihak lainnya.

Dalam usaha melakukan komunikasi antar umat beragama maka Pemerintah Daerah, MUI, Departemen Agama, dan FKUB Kota Tanjung Balai melakukan langkahlangkah sebagai berikut:

1) Meningkatkan konsolidasi, dialog kemitraan secara lebih intensif baik interen maupun antar umat beragama dan pemuka agama sesuai dengan kondisi daerah Kota Tanjung Balai.

2) Meningkatkan koordinasi, konsultasi secara periodik dengan Pemerintah Daerah Kota Tanjung Balai, Departemen Agama Tanjung Balai, MUI, maupun intansi terkait lainnya termasuk pemuka agama.

3) Meningkatkan peran dan pemberdayaan program Forum Kerukunan Umat Beragama Kota Tanjung Balai.

\section{PENUTUP}

Dari pembahasan penelitian ini dapatlah ditarik beberapa kesimpulan yaitu: Pertama, pola-pola komunikasi yang dikembangkan dalam meningkatkan hubungan umat beragama di Kota Tanjung Balai adalah dalam bentuk diskusi antar kelompok dengan mengedepankan sikap saling keterbukaan, saling pengertian sebagai bentuk dari manifestasi budaya bangsa Indonesia yang lemah lembut, santun, dan bijaksana. Kedua, untuk mengembangkan budaya komunikasi antarumat beragama maka pemerintah Daerah kota Tanjung Balai dan Forum Kerukunan Umat Beragama merumuskan program dialog antar umat. Ketiga, memberikan pemahaman tentang hidup bersama melalui pesan-pesan yang disampaikan oleh masing-masing pemuka agama dari lintas agama, agar kiranya mengedapankan nilai-nilai kemanusiaan yang sebenarnya sebagai bentuk kehadiran agama di tengah-tengah masyarakat. Sehingga masyarakat lebih mengutamakan kaum dhuafa. Sehingga terbentuklah pemahaman hubungan manusia dengan Tuhannya dan hubungan manusia dengan manusia serta implementasi dari 
hukum Islam yang Rahmatan Lil Alamin. Keempat, komunikasi atau dialog yang dilakukan dengan intensif dengan metode mediasi bisa menjadi paradigma baru bagi terjalinnya komunikasi antar umat beragama di Kota Tanjung Balai yang merupakan manifestasi dari hukum Islam yang mengedapankan nilai-nilai kemanusiaan (humanistik).

\section{REFERENSI}

Arifin, A. (1984). Strategi Komunikasi Suatu Pengantar Ringkas. Bandung: Armico.

Chandra, R. I. (1992). Konflik dalam Hidup Sehari-hari. Yogyakarta: Kanisius.

Daulay, H. (2001). Dakwah di Tengah Persoalan Budaya dan Politik. Yogyakarta: LESTI.

Hasibuan, S. (2017). Dinamika Hubungan Umat Beragama di Kota Tanjung Balai (Studi tentang Konflik Rumah Ibadah).

Hidayat, I. (2009). Teori-teori Politik. Malang: Setara Press.

Imarah, M. (1999). Islam dan Pluralitas (Perbedaan dan Kemajemukan dalam Bingkai Persatuan). Jakarta: Gema Insani Press.

Koeswinarno, \& Abdurrahman, D. (2006). Fenomena Konflik Sosial di Indonesia, dari Aceh sampai Papua. Yogyakarta: Lembaga Penelitian UIN Sunan Kalijaga.

Koran Sindo. (2016). Persoalan Ekonomi Dan Eksklusivitas Harus Dituntaskan | Koran Sindo | Sumber Referensi Terpercaya. Retrieved February 9, 2019, from http://koran-sindo.com/page/news/2016-08-01/5/1.

Outhwaite, W. (2008). The Blackwell Dictionary of Modern Social Thought (Kamus Lengkap Pemikiran Sosial Modern). (T. W. BS, Trans.) (Kedua). Jakarta: Kencana Prenada Media Grup.

Pelly, U. (1999). Akar Kerusuhan Etnik di Indonesia: Suatu Kajian Awal Konflik dan Disintegrasi Nasional di Era Reformasi. Jurnal Antropologi Indonesia, (58).

Ridwan, N. A. (2007). Landasan Keilmuan Kearifan Lokal. Ibda', 5(1).

Sulaeman, M. M. (2015). Konflik Pendekatan Ilmiah Modern dan Model Tradisional Berbasis Pengetahuan Lokal (Kasus di Desa Gadingan Kecamatan Sliyeg Kabupaten Indramayu). Sosiohumaniora, 17(1), 41-48.

https://doi.org/10.24198/sosiohumaniora.v17i1.5671.

Suparto, D. (2014). Konflik Identitas Sosial Masyarakat Temanggung (Kajian Kekerasan Sosial di Temanggung Tahun 2011). Politika: Jurnal Ilmu Politik, 4(2), 47-61. https://doi.org/10.14710/POLITIKA.4.2.2013.47-61. 